\title{
Modul Panduan Pelatihan Kesadaran Kesetaraan Gender bagi Siswa SMP sebagai Upaya Mempromosikan Pendidikan Damai
}

\author{
Inta Elok Youarti ${ }^{1}$, Carolina L. Radjah ${ }^{1}$, Dany M. Handarini ${ }^{1}$ \\ ${ }^{1}$ Bimbingan dan Konseling-Universitas Negeri Malang
}

\begin{tabular}{l} 
INFO ARTIKEL \\
\hline Riwayat Artikel: \\
Diterima: 04-07-2019 \\
Disetujui: 22-10-2019 \\
\hline
\end{tabular}

Kata kunci:

training guides; gender equality awareness; wayang golek; counselor: panduan pelatihan; kesadaran kesetaraan gender; wayang golek; konselor

\begin{abstract}
ABSTRAK
Abstract: This article contains a study of the research results on increasing gender equality awareness of junior high school students. The paradigm used in this context was the optimization of the roles and services of junior high school counselors. The approach used Research and Development (R \& D Research) which was initiated by Borg \& Gall with the main focus of developing gender equality awareness training guides for these junior high school students. Overall results of product trials and improvements that have been made indicate that the module is worthy of being used as a training guide and has the potential to be a media to promote peaceful education that can enhance students' understanding of the urgency and benefits of having gender equality awareness.
\end{abstract}

\begin{abstract}
Abstrak: Artikel ini berisi kajian hasil penelitian tentang upaya meningkatkan kesadaran kesetaraan gender siswa SMP. Paradigma yang digunakan dalam konteks ini adalah optimalisasi peran dan layanan konselor SMP. Pendekatan yang digunakan adalah Penelitian dan Pengembangan yang digagas oleh Borg \& Gall dengan fokus utama pengembangan panduan pelatihan kesadaran kesetaraan gender bagi siswa SMP tersebut. Keseluruhan hasil uji coba produk dan perbaikan yang telah dilakukan menunjukkan bahwa modul layak dijadikan sebagai panduan pelatihan serta potensial untuk menjadi media mempromosikan pendidikan damai yang dapat meningkatkan pemahaman siswa tentang urgensi dan manfaat memiliki kesadaran kesetaraan gender.
\end{abstract}

\author{
Alamat Korespondensi: \\ Inta Elok Youarti \\ Bimbingan dan Konseling \\ Universitas Negeri Malang \\ Jalan Semarang 5 Malang \\ E-mail: irnello183@gmail.com
}

Komitmen bangsa Indonesia untuk turut serta mewujudkan perdamaian dunia merupakan sebuah konsepsi nilai luhur yang patut diapresiasi setinggi-tingginya. Hal tersebut dikarenakan jauh sebelum banyak pengkajian tentang SDG yang salah satu tujuannya menciptakan perdamaian, keadilan, dan pelembagaan yang kuat. Namun, ternyata banyak tantangan yang harus dihadapi dalam proses mewujudkannya. Misalnya, perkembangan zaman yang berbanding lurus dengan jumlah konflik yang ada di masyarakat. Salah satunya adalah konflik berbasis gender yang tidak lagi mengenal batasan usia.

Sebuah survei yang dilakukan oleh (Komnas Perempuan, 2018) memaparkan beberapa temuan, yaitu (1) selama tahun 2017 terdapat lebih dari 10 kasus kekerasan berbasis gender yang dialami oleh siswa SMP di Indonesia; (2) kasus kekerasan berbasis gender juga diungkap oleh peneliti-peneliti asing seperti dalam buku Gender Based Violance milik (Djamba \& Kimuna, n.d.) yang berbicara tentang kekerasan berbasis gender di Afrika, di Cameroon, di Afrika Selatan, Halkovic, (2017) dan Siu, Wight, \& Seeley (2018) di Uganda; (3) mayoritas pelaku dari kasus tersebut adalah orang-orang yang dekat dengan korban. Secara tidak langsung, temuan yang ada telah menjadi peringatan keras bahwa konflik berbasis gender yang selalu berkaitan dengan kesetaraan harus mendapatkan perhatian khusus. Bahkan World Bank menyampaikan bahwa kesetaraan gender merupakan persoalan pokok pembangunan yang akan memperkuat kemampuan negara untuk berkembang, mengurangi kemiskinan dan memerintah secara efektif (Probosiwi, 2015). Apabila konflik yang ada tidak dapat di manajemen dengan baik, maka tujuan pembangunan nasional serta komitmen perdamaian pun akan sulit untuk diwujudkan.

Berbicara tentang kesetaraan gender bukanlah berbicara tentang persaingan antara laki-laki dan perempuan, bukan juga tentang pengalihtanganan tugas dan peranan, tetapi bagaimana seorang tidak didiskriminasikan karena gendernya (Osório, 2019). Apabila dilakukan analisis lebih lanjut, secara teoritis siswa Sekolah Menengah Pertama adalah mereka yang berada pada tahap remaja awal dengan rentang usia antara 12-15 tahun. Pada usia ini, siswa berada dalam masa pubertas, dimana terjadi transisi dan perkembangan pada dirinya baik secara fisik, psikis, maupun secara sosial. Siswa mulai meninggalkan peran sebagai anak-anak dan berusaha tidak tergantung pada orangtua. Fokus dari tahap yang ada yaitu penerimaan terhadap bentuk 
kondisi fisik serta berupaya mengembangkan diri melalui pergaulan dengan membentuk teman sebayanya (Wendari, Badrujaman, \& Sismiati, 2016). Di lain sisi, upaya membangun kesadaran yang baik atas kesetaraan gender pada generasi siswa SMP juga masih belum cukup optimal.

Sebuah penelitian dengan fokus yang sama menunjukkan bahwa (1) adanya diskriminasi yang terjadi dalam masyarakat sehingga menimbulkan dominasi terhadap jenis kelamin tertentu dalam bentuk stereotipe, beban ganda, dan kekerasan. Hal ini disebabkan oleh bangunan kurikulum yang bias gender; (2) bahan ajar atau buku-buku yang dipergunakan banyak yang tidak mencerminkan kesetaraan gender. Sebagai contoh dalam materi pelajaran tertentu, selalu mencantumkan maskulinitas atau laki-laki sebagai sosok yang lebih sempurna dan kuat dibanding perempuan sehingga tugas yang strategis lebih diidentikkan hanya cocok bagi laki-laki, seperti seorang pemimpin harus laki-laki (Khotimah, 2008). Dampak dari kondisi yang demikian ini adalah tingkat kesadaran kesetaraan gender cenderung rendah sehingga angka konflik kekerasan berbasis gender sendiri sulit untuk ditekan. Secara otomatis, kondisi ini juga menunjukkan bahwa pendidikan damai masih belum dapat dilakukan secara maksimal.

Dalam kajian teoritis disampaikan bahwa pendidikan damai merupakan kegiatan yang mengembangkan pengetahuan, keterampilan, dan sikap yang diperlukan untuk mengeksplorasi konsep perdamaian, menyelidiki hambatan menuju perdamaian, untuk menyelesaikan konflik dengan cara yang adil dan tanpa kekerasan dan untuk mempelajari cara membangun alternatif masa depan yang berkelanjutan (Hicks dalam Jegede, Ememe, \& Gami, 2014; Bajaj, 2015; Galtung, 1973). Istilah kekerasan yang digunakan dalam penjelasan tersebut didasari oleh serangkaian trauma akibat pertumpahan darah dan pelanggaran HAM pada saat perang dunia pertama dan kedua, termasuk kekerasan gender (Gupta, 2012). Pada konteks penerapan pendidikan damai, siswa didorong untuk memiliki pemahaman dan kesadaran bahwasanya konflik yang terjadi di masyarakat merupakan bagian dari dinamika sosial yang tidak dapat dihindari, namun harus dihadapi dengan manajemen diri yang baik. Untuk sampai pada tahapan manajemen diri tersebut, siswa harus mendapatkan penanaman teori yang baik serta pengalaman belajar yang menjadikan ia dekat dengan konten-konten kontekstual di masyarakat (Bauerlein, 2012). Sehingga siswa mendapatkan pemahaman yang tidak imajiner tentang merawat perdamaian tanpa jalan kekerasan. Mereka akan terdorong menjadi orangorang yang memiliki kesadaran tinggi dan siap menghadapi tantangan masa depan dengan penuh kearifan untuk mewujudkan konsep perdamaian di masyarakat.

Hakikat dari pendidikan damai tersebut sesungguhnya sejalan dengan jati diri bimbingan dan konseling yang selalu berupaya memberikan pendampingan pada siswa untuk mampu menghadapi serta menyelesaikan setiap tantangan perkembanganya yang ditemui di masyarakat. Dalam konteks ini, permasalahan kekerasan atau ketidaksetaraan gender juga menjadi substansi dari layanan pendampingan yang ada. Secara tidak langsung pernyataan ini menunjukkan sebuah kesimpulan awal bahwa bimbingan dan konseling menjadi pihak yang sangat berkompetensi untuk mengkonstruksi pendidikan damai dengan fokus kesetaraan gender dalam dunia pendidikan.

Sementara itu, untuk mengoptimalkan peran bimbingan dan konseling sebagai bentuk lain dari pendidikan damai yang berupaya membangun kesadaran kesetaraan gender, media pembelajaran juga menjadi hal yang harus diperhatikan. Bertolak pada hasil penelitian (Khotimah, 2008) yang telah dibahas sebelumnya bahwa jika ingin siswa memiliki Kesadaran kesetaraan gender, maka bahan ajar serta media yang digunakan oleh guru juga harus sarat akan nilai-nilai kesetaraan gender itu sendiri. Namun, agar tidak menimbulkan asumsi "heavy topics", maka guru bimbingan dan konseling dapat melakukan berbagai macam inovasi yang sekiranya menjadikan proses pembelajaran tentang kesetaraan gender dapat direspons dengan baik oleh siswa sebagai konten yang menarik sehingga tujuan penerapan pendidikan damai pun dapat terwujud secara nyata.

Maka dari itu, melihat serangkaian permasalahan serta potensi-potensi yang ada, dilakukan kajian lebih lanjut tentang Pengembangan Panduan Kesadaran Kesetaraan Gender sebagai Upaya Mempromosikan Pendidikan Damai. Mengingat bahwa belum terdapat kajian dengan konten dan fokus serupa. Melalui kegiatan pengembangan diharapkan dapat terlahir sebuah rujukan tentang optimalisasi peran guru bimbingan dan konseling dalam mengkonstruksi pendidikan damai dalam dengan tujuan membangun kesadaran kesetaraan gender siswa. Sehingga gender tidak lagi dipahami sebagai topik yang selalu memberikan stigma negatif karena banyaknya permasalahan yang terkait, namun sebagai sebuah topik pembelajaran yang positif dan menarik untuk dibahas baik dalam diskusi khusus maupun umum. Secara tidak langsung, komitmen serta cita-cita perdamaian pun dapat diwujudkan oleh pata generasi muda yang menjadi tombak pembangunan bangsa.

\section{METODE}

Model pengembangan Research and Development digunakan berdasarkan beberapa pertimbangan, salah satunya (1) model pengembangan ini dimulai dengan meneliti dan mengumpulkan informasi. Pengembangan panduan kesadaran kesetaraan gender siswa sebagai upaya mempromosikan pendidikan damai ini juga dimulai dengan melakukan wawancara kepada konselor SMP dan penelitian awal dengan penyebaran angket skala kesadaran gender pada siswa SMP; (2) model pengembangan ini sederhana dan fleksibel karena dapat dipilih tahap mana saja yang sesuai dengan kebutuhan. Pernyataan tersebut sesuai dan cocok untuk mengembangkan panduan paket pelatihan kesadaran kesetaraan gender siswa sebagai upaya mempromosikan pendidikan damai; (3) strategi pengembangan dipilih karena langkah-langkah pelaksanaan yang jelas, terperinci, dan sistematis.

Prosedur pengembangan modul panduan pelatihan kesadaran kesetaraan gender dilakukan melalui tiga tahap. Pertama, tahap pra pengembangan, yaitu tahap untuk mengumpulkan informasi yang berkaitan dengan masalah pengembangan panduan paket pelatihan kesadaran kesetaraan gender bagi siswa SMP. Pengumpulan informasi dilakukan dengan need assessment, 
untuk menetapkan perlunya panduan ini disusun. Kedua, tahap pengembangan dilaksanakan dengan beberapa kegiatan, yaitu (a) merumuskan tujuan, (b) membuat instrumen, dan (c) menyusun prototype produk pengembangan panduan kesadaran kesetaraan gender yang terdiri dari buku panduan pelatihan kesadaran kesetaraan gender bagi konselor. Ketiga, tahap pasca pengembangan. Pada tahap ini dilakukan uji coba, meliputi (a) uji coba ahli yang terdiri dari ahli Bimbingan dan Konseling dan ahli media, (b) uji coba calon pengguna (konselor SMP). Instrumen pengumpulan data yang digunakan adalah skala penilaian yang memuat tentang aspek kegunaan, ketepatan, kelayakan, dan kepatutan panduan dengan skala penilaian dan interpretasinya sebagai berikut.

Tabel 1. Interpetasi Skala Penilaian Uji Ahli

\begin{tabular}{cl}
\hline Skala & \\
\hline 1 & $\begin{array}{l}\text { Sangat Tidak Jelas, Sangat tidak tepat, Sangat tidak praktis, Sangat tidak relevan, Sangat tidak } \\
\text { perlu, Sangat tidak bermanfaat, Sangat tidak penting }\end{array}$ \\
2 & $\begin{array}{l}\text { Tidak Jelas, tidak tepat, tidak praktis, tidak relevan, tidak perlu, tidak bermanfaat, tidak penting } \\
3\end{array}$ \\
$\begin{array}{l}\text { Jelas, Tepat, Praktis, Relevan, Perlu, Bermanfaat, Penting } \\
\text { Sangat Jelas, Sangat tepat, Sangat praktis, Sangat relevan, Sangat perlu, Sangat bermanfaat, Sangat } \\
\text { penting }\end{array}$ \\
\hline
\end{tabular}

Sementara itu, analisis atas data yang telah diperoleh dilakukan mengelompokkan terlebih dahulu jenis data yang ada ke dalam dua kategori, yaitu data angka dan non angka. Data yang berupa angka atau kuantitatif dianalisis menggunakan analisa statistic deskriptif dengan pengukuran tendensi sentral mode (modus). Data yang bersifat non angka, seperti saran, masukan dan kritik akan ditarik kesimpulan, sehingga dapat dipertimbangkan untuk merevisi produk.

\section{HASIL}

Setelah melalui serangkaian tahapan penelitian dan pengembangan, dihasilkan produk berupa modul Panduan Pelatihan Kesadaran Kesetaraan Gender untuk Siswa SMP. Substansi dari modul terdiri dari pendahuluan, petunjuk umum, dan prosedur pelatihan. Sebelum digunakan secara langsung di lapangan, dilakukan beberapa uji yang meliputi uji coba produk dengan ahli serta uji coba produk dengan calon pengguna yang menunjukkan hasil sebagai berikut.

Validasi Uji Ahli Bimbingan Konseling

Tabel 2. Hasil Validasi Uji Ahli Bimbingan Konseling

\begin{tabular}{|c|c|c|c|}
\hline \multirow[b]{2}{*}{ No } & \multirow[b]{2}{*}{ Aspek Penilaian } & \multicolumn{2}{|c|}{ Ahli BK } \\
\hline & & $\begin{array}{c}\text { BK } \\
1\end{array}$ & $\begin{array}{c}\text { BK } \\
2\end{array}$ \\
\hline 1. & Kemudahan melaksanakan langkah-langkah dalam panduan pelatihan kesadaran kesetaraan gender & 4 & 3 \\
\hline 2. & $\begin{array}{l}\text { Efisiensi jumlah tenaga yang diperlukan untuk melaksanakan pelatihan kesadaran kesetaraan gender sebagaimana yang } \\
\text { dirancang pada produk. }\end{array}$ & 3 & 3 \\
\hline 3. & $\begin{array}{l}\text { Efisiensi waktu yang diperlukan untuk melaksanakan pelatihan kesadaran kesetaraan gender sebagaimana yang } \\
\text { dirancang pada produk. }\end{array}$ & 3 & 2 \\
\hline 4. & Dampak pengembangan panduan pelatihan kesadaran kesetaraan gender sebagai pendekatan yang "cost beneficial" & 3 & 3 \\
\hline
\end{tabular}

Berdasarkan tabel 2 dapat diketahui bahwa langkah-langkah dalam panduan pelatihan kesadaran kesetaraan gender dapat dilakukan dengan sangat mudah. Selanjutnya, butir efisiensi jumlah tenaga yang diperlukan untuk melaksanakan pelatihan kesadaran kesetaraan gender diniliai efisien. Berikutnya item efisiensi waktu yang dibutuhkan untuk melaksanakan pelatihan kesadaran kesetaraan gender sudah efisien. Dan yang terakhir adalah pengembangan panduan pelatihan kesadaran kesetaraan gender berdampak besar untuk memilih pendekatan pelatihan yang cost benefical. Saran dan masukan yang diberikan ahli bimbingan konseling terhadap produk yang dihasilkan antara lain (1) diperbaiki kesalahan penulisan, (2) perlu ditentukan secara pasti alokasi waktu yang diperlukan agar konselor di lapangan mudah dalam merancang kegiatan ini (disesuaikan dengan kegiatan sekolah), (3) rumusan tujuan sebaiknya dijabarkan dalam tujuan khusus untuk setiap pertemuan, dan (4) pada pertemuan keempat ada sinopsis yang terlalu vulgar untuk konsumsi siswa SMP. 


\section{Validasi Ahli Media \\ Tabel 3. Hasil Uji Validasi Ahli Media}

\begin{tabular}{|c|c|c|}
\hline No & Aspek Penilaian & Ahli Media \\
\hline \multicolumn{3}{|c|}{ Kegrafisan } \\
\hline 1. & Kemenarikan sampul buku panduan pelatihan kesadaran kesetaraan gender & 3 \\
\hline 2. & Kemenarikan warna sampul buku panduan pelatihan kesadaran kesetaraan gender & 4 \\
\hline 3. & Kemenarikan desain sampul buku panduan pelatihan kesadaran kesetaraan gender & 3 \\
\hline 4. & Kemenarikan desain halaman isi buku panduan pelatihan kesadaran kesetaraan gender & 3 \\
\hline 5. & Kemenarikan jenis huruf serta struktur penulisan pada buku panduan pelatihan kesadaran kesetaraan gender & 4 \\
\hline \multicolumn{3}{|c|}{ Kebahasaan } \\
\hline 6. & Kemenarikan jenis huruf yang digunakan dalam buku panduan & 3 \\
\hline 7. & Kemenarikan gaya penulisan buku panduan & 4 \\
\hline 8. & Kemenarikan struktur kepenulisan pada buku panduan & 4 \\
\hline
\end{tabular}

Berdasarkan tabel 3 diketahui bahwa sampul buku panduan pelatihan kesadaran kesetaraan gender menarik. Selanjutnya desain sampul buku panduan pelatihan kesadaran kesetaraan gender dinyatakan menarik. Pada indikator kegrafisan adalah desain halaman isi buku panduan pelatihan kesadaran kesetaraan gender dinyatakan menarik. Selanjutnya, jenis huruf serta struktur penulisan pada buku panduan pelatihan kesadaran kesetaraan gender dinilai sangat menarik.

Indikator kedua dari aspek kemenarikan yang dinilai oleh ahli media pembelajaran adalah indikator kebahasaan. Pada indikator ini, butir pertama adalah jenis huruf yang digunakan dalam buku panduan mendapatkan penilaian menarik dari ahli. Dua butir terakhir pada indikator ini adalah gaya penulisan buku panduan dan struktur kepenulisan pada buku panduan dinyatakan sangat menarik oleh ahli. Saran dan masukan yang diberikan ahli media untuk revisi produk yaitu desain sampul harap disempurnakan lagi.

\section{Validasi Calon Pengguna}

Tabel 4. Hasil Uji Validasi Calon Pengguna

\begin{tabular}{|c|c|c|c|}
\hline \multirow[t]{2}{*}{ No } & \multirow[t]{2}{*}{ Aspek Penilaian } & \multicolumn{2}{|c|}{$\begin{array}{c}\text { Calon } \\
\text { Pengguna }\end{array}$} \\
\hline & & KO 1 & KO 2 \\
\hline \multicolumn{4}{|c|}{ Indikator I: Kepraktisan Panduan Pelatihan Kesadaran Kesetaraan Gender } \\
\hline 1. & Kemudahan melaksanakan langkah-langkah dalam panduan pelatihan kesadaran kesetaraan gender & 3 & 4 \\
\hline \multicolumn{4}{|c|}{ Indikator II: Efisiensi Panduan Pelatihan Kesadaran Kesetaraan Gender } \\
\hline 2. & $\begin{array}{l}\text { Efisiensi jumlah tenaga yang diperlukan untuk melaksanakan pelatihan kesadaran kesetaraan gender sebagaimana } \\
\text { yang dirancang pada produk. }\end{array}$ & 3 & 3 \\
\hline 3. & $\begin{array}{l}\text { Efisiensi waktu yang diperlukan untuk melaksanakan pelatihan kesadaran kesetaraan gender sebagaimana yang } \\
\text { dirancang pada produk. }\end{array}$ & 3 & 3 \\
\hline 4. & Dampak pengembangan panduan pelatihan kesadaran kesetaraan gender sebagai pendekatan yang "cost beneficial" & 3 & 4 \\
\hline
\end{tabular}

Berdasarkan tabel 4 dapat diketahui bahwa langkah-langkah dalam panduan pelatihan kesadaran kesetaraan gender sangat mudah dilaksanakan. Selanjutnya jumlah tenaga dan waktu yang diperlukan untuk melaksanakan pelatihan kesadaran kesetaraan gender efisien. Butir terakhir pengembangan panduan pelatihan kesadaran kesetaraan gender berdampak sangat besar untuk memilih pendekatan pelatihan yang cost benefical.

\section{PEMBAHASAN}

\section{Analisis Hasil Uji Coba Produk Oleh Ahli}

\section{Hasil Uji Coba Produk oleh Ahli Bimbingan dan Konseling}

Hasil analisis uji coba oleh ahli bimbingan dan konseling secara umum menunjukkan bahwa modul panduan pelatihan yang ada memiliki peluang diterima yang cukup besar karena pada konten kegunaan, kelayakan dan ketepatan mendapatkan penilaian yang baik. Penilaian ini penting adanya disebabkan oleh tujuan utama dari pengembangan panduan pelatihan berkaitan dengan penanaman kesadaran kesetaraan gender melalui pelatihan berbasis layanan bimbingan dan konseling. Maka secara otomatis karakteristik dan rambu-rambu Bimbingan dan Konseling harus termuat secara baik pula di dalam panduan pelatihan tersebut.

Misalnya, aspek kegunaan yang terdapat pada indikator II tentang ruang lingkup panduan pelatihan khususnya relevansi panduan pelatihan kesadaran kesetaraan gender apabila diterapkan pada siswa SMP serta aspek ketepatan pada indikator I tentang ketepatan prosedur pelatihan kesadaran kesetaraan gender. Pada kedua aspek dan indikator tersebut, ahli Bimbingan dan Konseling memberikan penilaian yang baik. Berdasarkan hasil tersebut, dapat ditarik kesimpulan bahwa substansi dalam panduan pelatihan sudah relevan dengan konteks kebutuhan siswa akan kesadaran kesetaraan gender. Relevansi 
sendiri juga dapat dipahami sebagai istilah untuk menunjukkan kualitas dari substansi yang ada berkaitan dengan tujuan pengembangan panduan pelatihan. Hasil ini sejalan dengan penelitian yang dilakukan oleh Khotimah (2008) bahwa jika ingin siswa memiliki kesadaran kesetaraan gender, maka bahan ajar serta media yang digunakan oleh guru juga harus sarat akan nilainilai kesetaraan gender itu sendiri.

\section{Hasil Uji Coba Produk oleh Ahli Media Pembelajaran}

Dari kegiatan pengujian didapatkan berbagai macam penilaian yang berkaitan dengan "penyajian" panduan pelatihan sebagai sebuah media pembelajaran. Dari 14 butir penilaian, delapan butir mendapatkan penilaian yang maksimal atau sangat menarik, sedangkan enam butir lainnya mendapatkan penilaian menarik dari ahli media pembelajaran. Kondisi ini juga dapat dikategorikan sebagai bentuk keberhasilan inovasi atau pengembangan yang ada. Apabila ditinjau dari sisi teoritis tentang pembelajaran kesetaraan gender, berdasarkan pada penelitian yang dilakukan oleh Khotimah (2008) didapatkan sebuah temuan bahwa agar tidak menimbulkan asumsi "heavy topics", maka guru Bimbingan dan Konseling dapat melakukan berbagai macam inovasi yang sekiranya menjadikan proses pembelajaran tentang kesetaraan gender dapat direspon dengan baik oleh siswa sebagai konten yang menarik.

Dari kedua analisis hasil uji coba dengan ahli, secara keseluruhan didapatkan kesimpulan bahwa panduan pelatihan yang dikembangkan oleh peneliti sudah layak dan siap untuk digunakan sebagai salah satu referensi utama untuk dijadikan sebagai media penanaman kesadaran kesetaraan gender bagi siswa SMP. Dari sisi substansi, penyajian, serta komponen media pembelajaran yang terkandung di dalamnya telah melalui pengujian oleh para ahli di bidangnya sehingga proses revisi juga telah dilakukan agar kualitas yang ada betul-betul dapat menjadi sebuah solusi atas permasalahan tingginya angka kekerasan berbasis gender di lingkungan siswa SMP.

\section{Analisis Hasil Uji Coba Calon Pengguna Produk}

Berdasarkan data yang tersaji dalam hasil uji coba pengguna terhadap aspek kegunaan panduan, terutama indikator I yang berkaitan dengan persyaratan bagi pengguna yang meliputi pernyataan-pernyataan urgensi akan panduan yang dikembangkan oleh peneliti. Dari ketiga item yang disajikan, hampir semua item dan pengguna menunjukkan bahwa mereka perlu untuk memperoleh pendidikan khusus tentang kesetaraan gender dan memiliki kompetensi yang terkait dengan itu. Paparan ini secara jelas menunjukkan bahwa penelitian pengembangan yang dilakukan oleh peneliti memang sesuai dengan kebutuhan di lapangan. Temuan ini memperkuat hasil pra pengembangan baik yang berupa kajian literatur maupun survei yang memiliki hasil sejenis bahwa isu gender merupakan isu yang penting untuk dipahami lebih dalam pada abad ini (Otto, 2013; Bericat, 2012; Bericat \& Sa, 2016). Sehingga penting untuk dibahas melalui jalur pendidikan dan guru pun perlu memiliki pemahaman dan kompetensi untuk membahasnya secara khusus.

Selain sisi substansi, hasil uji coba oleh calon pengguna juga memberikan sebuah gambaran tentang kebermanfaatan produk pengembangan panduan pelatihan. Pada aspek kegunaan yaitu indikator $\mathrm{V}$ tentang dampak penggunaan panduan pelatihan terdapat butir kebermanfaatan panduan pelatihan di bidang membantu siswa mencapai tujuan pendidikan damai. Item ini mendapatkan penilaian maksimal dari responden. Saat hasil uji coba menunjukkan angka yang relatif tinggi, maka secara tidak langsung konten materi pendidikan damai yang disajikan pun telah dipahami dengan baik oleh pengguna. Dengan demikian, dapat dikatakan bahwa panduan pelatihan telah sejalan dengan tujuan dari pengembangan sehingga dirasakan memberi manfaat oleh penggunanya. Data ini juga dapat menjadi bukti kesuksesan awal media sosialisasi nilai-nilai kesetaraan gender melalui jalur pendidikan, terutama pendidikan damai yang dikemas dalam panduan yang ada.

Butir penilaian kebermanfaatan produk oleh calon pengguna ini merupakan komponen yang penting karena pada dasarnya pendidikan damai sendiri dipahami secara khusus mengarah pada upaya terencana untuk mendorong warga negara dapat berkontribusi secara efektif pada perkembangan budaya, sosial, ekonomi, dan politik negara (Chinyere, 2013). Apabila para calon pengguna merasa bahwa substansi panduan pelatihan yang dikembangkan oleh peneliti kurang memberikan manfaat maka akan jelas berdampak pada ketidaktercapaiannya kontribusi pengguna sebagai warga negara dalam penyelesaianpenyelesaian konflik gender tanpa kekerasan. Namun, karena hasilnya adalah bermanfaat, maka besar peluang panduan pelatihan ini dapat menjadi referensi utama dalam melakukan kaderisasi warga negara yang memiliki kesadaran kesetaraan gender yang baik dan penuh cinta damai.

\section{SIMPULAN}

Pendidikan damai merupakan realisasi dari komitmen bangsa Indonesia untuk turut serta mewujudkan perdamaian dunia dan mendukung terpenuhinya cita-cita pembangunan berkelanjutan. Dalam konteks ini, konflik-konflik di manajemen dengan baik agar tidak menimbulkan dinamika sosial yang merugikan. Salah satu konflik yang perlu mendapatkan perhatian khusus saat ini adalah konflik kekerasan berbasis gender. Peningkatan angka dari isu tersebut telah merambah ke rentang usia belajar yaitu siswa-siswi SMP yang harus segera mendapatkan jalan pemutusan rantai permasalahan. Hal ini terjadi diakibatkan kurangnya pemahaman dan kesadaran atas kesetaraan gender itu sendiri. Sebagai upaya memutuskan mata rantai permasalahan yang ada melalui jalur pendidikan, maka dikembangkan lah sebuah modul panduan pelatihan kesadaran kesetaraan gender bagi konselor. Melalui serangkaian tahapan pengembangan dan pengujian oleh ahli maupun calon pengguna, modul panduan 
pelatihan ini memenuhi unsur kelayakan, ketepatan, serta kegunaan sebagai salah satu referensi unggulan untuk mempromosikan pendidikan damai sebagai resolusi konflik berbasis gender (zero violence). Permasalahan kurang maksimalnya pelayanan guru Bimbingan dan Konseling di SMP tentang layanan kesetaraan gender dikarenakan tidak ada panduan pelatihan sehingga terbuka kesempatan yang luas bagi lahirnya generasi-generasi muda Indonesia yang cerdas dan mencintai perdamaian.

Pada sisi kebermanfaatan, hasil kajian dari konten ini dapat menjadi rujukan bagi para praktisi di bidang bimbingan dan konseling untuk mempromosikan pendidikan damai melalui penggunaan panduan pelatihan kesadaran kesetaraan gender. Pada sisi keberlanjutan, prosedur yang dijalankan pada R \& D ini terbatas hanya sampai pada tahapan pengembangan produk, maka peneliti yang memiliki minat kajian sejenis dapat memperluas pengkajian pada tahapan mengukur pengaruh dari penggunaan modul panduan pelatihan terhadap peningkatan kesadaran kesetaraan gender siswa SMP agar didapatkan kajian yang lebih komprehensif.

\section{DAFTAR RUJUKAN}

Bajaj, M. (2015). Pedagogies of Resistance and Critical Peace Education Praxis. Journal of Peace Education, 12(2), $154-166$. https://doi.org/10.1080/17400201.2014.991914

Bajaj, M. (2016). Pedagogies of Resistance and Critical Peace Education Praxis, 0201(March). https://doi.org/10.1080/17400201.2014.991914

Bauerlein, M. (2012). Civic Literacy. Springer, 25, 328-333.

Bericat, E. (2012). The European Gender Equality Index: Conceptual and Analytical Issues, 1-28. https://doi.org/10.1007/s11205-011-9872-Z

Bericat, E., \& Sa, E. (2016). Structural Gender Equality in Europe and Its Evolution Over the First Decade of the Twenty First Century, 55-81. https://doi.org/10.1007/s11205-015-0949-y

Chinyere, N. (2013). Peace Education, Transformation of Higher Education and Youths Empowerment for Peace in Africa. International Journal of Scientific \& Technology Research, 2(12), 338-347.

Halkovic, A. (2017). Intersectional Investigations into Gender Based Violence. https://doi.org/10.1007/s11199-017-0801-8

Jegede, S., Ememe, P. I., \& Gami, T. O. (2014). Curbing Deviance Through Peace Education in Lagos State, 169-193.

Khotimah, K. (2008). Urgensi Kurikulum Gender dalam Pendidikan. Jurnal Pemikiran Alternatif Pendidikan, 13(3), 1-10.

Komnas Perempuan. (2018). Tergerusnya Ruang Aman Perempuan Dalam Pusaran Politik Populisme: Catatan Kekerasan terhadap Perempuan Tahun 2017. Jakarta.

Osório, A. (2019). Gender Differences in Competition: Gender Equality and Cost Reduction Policies. Review of Economic Design. https://doi.org/10.1007/s10058-019-00219-x

Otto, D. (2013). Melbourne Legal Studies Research Paper. Melbourne Law School, (620).

Siu, G. E., Wight, D., \& Seeley, J. (2018). Correction to : Men’ s Involvement in a Parenting Programme to Reduce Child Maltreatment and Gender-Based Violence: Formative Evaluation in Uganda. The European Journal of Development Research, 41287. https://doi.org/10.1057/s41287-018-0141-8

Wendari,W. N., Badrujaman, A., \& Sismiati, A. (2016). Profil Permasalahan Siswa Sekolah Menengah. Insight, 5(1), 134-139. 